\title{
Potensi Daya Dukung Limbah Kulit Singkong hasil Olahan Pothil sebagai Pakan Sapi Potong di Kecamatan Dukun, Magelang
}

\author{
Tri Puji Rahayu1, Candarisma Danes Noor Viana2, \\ Zahrotul Luklukyah3, Budi Irawan4 \\ 1Dosen Program Studi Peternakan Fakultas Pertanian Universitas Tidar \\ 2Dosen Program Studi Agroteknologi Fakultas Pertanian Universitas Tidar \\ 3Mahasiswa Program Studi Peternakan Fakultas Pertanian \\ Universitas Tidar \\ Corresponding E-mail : tripujirahayu@untidar.ac.id
}

\begin{abstract}
ABSTRAK
Penelitian ini bertujuan untuk mengkaji produksi bahan kering (BK) dan potensi kapasitas dukung sapi potong terhadap kulit singkong sebagai pakan. Penelitian dilakukan selama satu bulan, di Dusun Batur Ngisor, Desa Ngargomulyo dan Dusun Tutup Ngisor, Desa Sumber, Kecamatan Dukun, Magelang. Penelitian ini menggunakan metode survey dengan cara Purposive Sampling dengan pengambilan sampel sebanyak 9 responden produsen pothil di wilayah Kecamatan Dukun. Hasil penelitian menunjukkan bahwa produksi bahan kering kulit singkong dari olahan pothil di Kecamatan Dukun sebesar 506.795,02 ton/tahun. Jika dihitung berdasarkan daya dukung kulit singkong dari olahan pothil tersebut, maka Kecamatan Dukun mampu menampung sekitar 6768 ST (satuan ternak) atau 6768 ekor sapi potong dewasa setiap tahunnya. Oleh karena itu, kulit singkong dari olahan pothil di Kecamatan Dukun mampu mencukupi kebutuhan pakan bagi sapi potong.
\end{abstract}

Kata Kunci: kulit singkong, pothil, sapi potong, daya dukung.

\begin{abstract}
The research aims to studied the production of dry matter (DM) and potential capacity of beef cattle to cassava peels as feed. The study was conducted for one month, in the Batur Ngisor Hamlet, Ngargomulyo Village and the Ngisor Close Hamlet, Sumber Village, Dukun District, Magelang. This study used a survey method by means of Purposive Sampling by taking a sample of 9 respondents of pothil producers in the Dukun District. The results showed that the production of dried cassava peels material from processed pothil in Dukun District was 506.795,02 tons/year. If, the calculated based on the carrying capacity of cassava peels form processed pothil, furthermore Dukun District were able to accommodated around 6768 UT/ 6768 tails of beef cattle on year. Therefore, cassava peels from pothil processed in Dukun District were able to sufficient requirement feed to beef cattle.
\end{abstract}

Keywords: cassava peels, pothil, beef cattle, capacity. 


\section{PENDAHULUAN}

Magelang merupakan salah satu kabupaten di wilayah Jawa Tengah yang letaknya cukup strategis sebagai jalur transportasi, ekonomi maupun wisata lokal dan regional. Letak strategis inilah yang mendorong terciptanya berbagai variasi jajanan atau oleh-oleh khas Magelang salah satunya panganan berbahan dasar singkong. Kecamatan Dukun adalah satu kecamatan di Kabupaten Magelang yang aktif mengembangkan olahan singkong berupa pothil. Di wilayah ini hampir setiap desa melakukan produksi pothil untuk dipasarkan di wilayah Magelang, Yogyakarta dan sekitarnya. Pothil menjadi salah satu variasi makanan di wilayah Kabupaten Magelang sebagai pelengkap oleh oleh para pegunjung atau wisatawan yang datang. Olahan pothil tersebut mudah dijumpai di pasar tradisional, pusat oleh-oleh, maupun tempat wisata, hal ini dikarenakan banyaknya pelaku usaha yang memproduksi produk olahan makanan tersebut. Rendahnya biaya produksi menjadi salah satu hal yang dipertimbangkan oleh pelaku usaha sebagai produsen produk olahan makanan tersebut.

Olahan makanan yang berupa pothil singkong tidak hanya memberikan keuntungan bagi para pelaku usaha, tetapi juga memberikan efek negatif baik bagi lingkungan maupun produsen itu sendiri. Salah satu sisi negatif yang perlu diperhatikan yaitu limbah dari kegiatan produksi yang berupa kulit singkong. Singkong yang digunakan sebagan bahan dasar produk olahan hanya singkong yang telah dikuliti, sehingga kulitnya hanya dibuang begitu saja. Hal ini menimbulkan masalah terutama untuk produksi olahan dengan kapasitas yang besar. Persentase kulit singkong yang dihasilkan setelah dikuliti kurang lebih 20\%, sehingga ketika industri olahan berbahan dasar singkong memanfaatkan singkong sebanyak $100 \mathrm{~kg}$ dalam sehari, maka limbah yang dihasilkan sebesar 20 $\mathrm{kg}$ (Hanifah et al., 2010). Apabila ada sebanyak 30 orang produsen pothil di Kecamatan Dukun, Magelang membutuhkan sekitar $100 \mathrm{~kg} /$ produksi singkong sebagai bahan dasarnya, maka limbah kulit singkong yang dihasilkan sebesar 600 $\mathrm{kg} /$ produksi.

Jika dikaji lebih lanjut, kulit singkong dapat dimanfaatkan salah satunya sebagai pakan ternak. Potensi limbah kulit singkong sebagai pakan sapi potong cukup besar melalui berbagai bentuk teknologi dan perlakuan pengolahannya. Pemanfaatan limbah kulit singkong menjadi salah satu solusi untuk mengatasi permasalahan para peternak dalam memenuhi kebutuhan pakan sapi potong. Harapannya mampu menghitung daya dukung sapi potong terhadap limbah kulit singkong di Kecamatan Dukun, Kabupaten Magelang Penelitian ini bertujuan untuk mengkaji potensi dan daya dukung limbah kulit singkong dari olahan pothil singkong di Kabupaten Magelang.

\section{MATERI DAN METODE}

Materi yang digunakan dalam penelitian ini yaitu produsen pothil di Kecamatan Dukun, data populasi ternak pada lokasi terpilih, kuisioner responden, sampel kulit singkong yang dikeringkan. Penelitian ini menggunakan metode survey dan observasi secara langsung di lokasi. Penentuan lokasi sampel menggunakan "Purposive Sampling" dipilih 9 responden. Penelitian ini dilaksanakan di Kecamatan Dukun pada bulan Juli sampai Agustus 2019 pada Dusun Batur Ngisor, Desa Ngargomulyo dan Dusun Tutup Ngisor, Desa Sumber. Parameter yang diukur yaitu produksi kulit singkong, daya dukung limbah kulit singkong terhadap sapi potong dan kandungan nutrien kulit singkong dari olahan pothil. Kulit singkong dari olahan pothil yang digunakan yaitu setelah dikupas, dikuliti dan dikeringkan.

\section{a. Perhitungan produksi bahan kering (BK) kulit singkong}

Dihitung berdasarkan produksi Bahan Kering (BK)

Produksi Total $\mathrm{BK}=$ Produksi $\mathrm{BK}$ (ton/thn) $\mathrm{x}$ jumlah total kulit singkong (ton)

\section{b. Perhitungan daya dukung kulit singkong dari olahan pothil (DDKSP)}

Dengan asumsi untuk satu satuan ternak (1 ST) sapi potong rata - rata membutuhkan bahan kering sebanyak 6,25 kg/hari atau 2.282,25 $\mathrm{kg} /$ tahun (NRC, 1985). Perhitungan kapasitas dukung ternak sebagai berikut:

$$
D D K S P=\frac{\text { Produksi BK }}{\text { Kebutuhan BK1ST/tahun }}
$$

\section{HASIL DAN PEMBAHASAN}

\section{Produksi Bahan Kering (BK) Kulit Singkong Olahan Pothil}

Pengamatan dan pengumpulan data produksi BK kulit singkong untuk olahan pothil dilakukan pada Dusun Batur Ngisor, Desa Ngargomulyo dan Dusun Tutup Ngisor, Desa Sumber. Pemilihan lokasi 
tersebut atas dasar data sentra produksi pothil rekomendasi dari Dinas Perindustrian dan Ketenagakerjaan dan Dinas Perdagangan, Koperasi dan UMKM Kabupaten Magelang. Selanjutnya, dilakukan survey dan pengisian kuisioner terhadap 9 orang responden selaku produsen pothil di wilayah Kecamatan Dukun, Magelang. Diperoleh jumlah produksi kulit singkong dari produsen pothil di Kecamatan Dukun sebesar 74,808 ton/tahun.

Produksi bahan kering (BK) kulit singkong dari olahan pothil diperoleh dengan cara menghitung produksi bahan kering dikalikan dengan jumlah total kulit singkong. Nilai bahan kering (BK) dari kulit singkong yang telah dikeringkan sebesar 90,56\%. Hasil penelitian menunjukkan bahwa perhitungan produksi total BK kulit singkong yang sudah dikeringkan dapat diperoleh melalui perhitungan sebagai berikut : Produksi Total BK $=$ Produksi BK (ton/thn) $\mathrm{x}$ jumlah total kulit singkong (ton). Produksi $\mathrm{BK}=90,56 \times 74.808$ $\mathrm{kg}=6.774 .612,48 \mathrm{~kg} / \mathrm{tahun}=6.774,61 \mathrm{ton} / \mathrm{tahun}$, sedangkan Produksi Total $\mathrm{BK}=6.774,61$ ton/tahun $\mathrm{x} 74,808$ ton/tahun $=506.795,02$ ton/tahun didasarkan dari produksi kulit singkong yang disajikan pada tabel 1.

\begin{tabular}{|c|c|c|c|}
\hline \multirow[b]{2}{*}{ No } & \multirow[b]{2}{*}{ Lokasi } & \multicolumn{2}{|c|}{ Pothil } \\
\hline & & $\begin{array}{c}\text { Jumlah } \\
\text { bahan baku } \\
\text { (kg/produksi } \\
\text { ) }\end{array}$ & $\begin{array}{c}\text { Produksi } \\
\text { kulit } \\
\text { singkong } \\
\text { (kg/produksi } \\
\text { ) }\end{array}$ \\
\hline 1 & 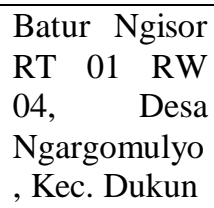 & 200 & 40 \\
\hline 2 & $\begin{array}{lr}\text { Batur } & \text { Ngisor } \\
\text { RT 01 RW } \\
\text { 04, Desa } \\
\text { Ngargomulyo } \\
\text {, Kec. Dukun }\end{array}$ & 80 & 16 \\
\hline 3 & \begin{tabular}{lr} 
Tutup Ngisor \\
RT 01 RW \\
$05 \quad$ Desa \\
Sumber, Kec. \\
\multicolumn{2}{l}{ Dukun }
\end{tabular} & 200 & 40 \\
\hline 4 & \begin{tabular}{lr} 
Tutup Ngisor \\
RT 02 RW \\
05 \\
Sumber, \\
Kec. \\
\multicolumn{2}{l}{ Dukun }
\end{tabular} & 60 & 12 \\
\hline 5 & \begin{tabular}{lr} 
Tutup Ngisor \\
RT 02 RW \\
$05 \quad$ Desa \\
Sumber, Kec. \\
\multicolumn{2}{l}{ Dukun }
\end{tabular} & 200 & 40 \\
\hline 6 & 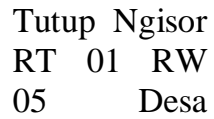 & 50 & 10 \\
\hline
\end{tabular}

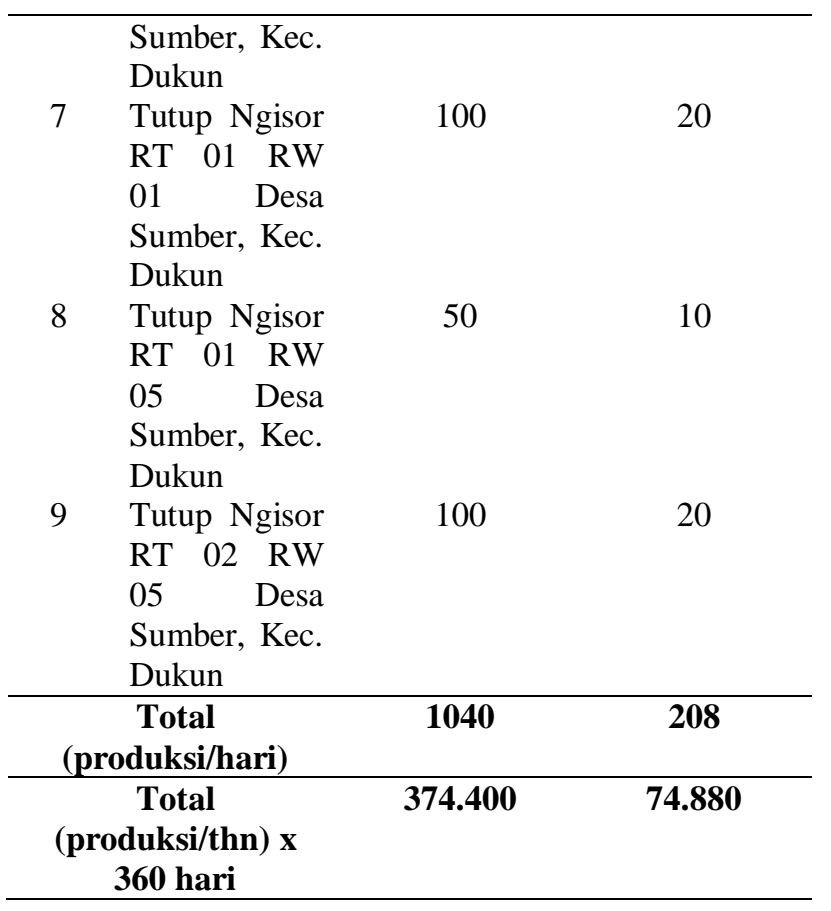

\section{Daya Dukung Kulit Singkong Olahan Pothil sebagai Pakan Sapi Potong}

Pemanfaatan limbah hasil olahan pothil berupa kulit singkong sebagai pakan sapi potong sudah menjadi kebiasaan bagi para peternak. Hal tersebut disebabkan karena sapi potong yang termasuk kedalam jenis ternak ruminansia mempunyai kemampuan mengkonversi bahan pakan yang mengandung serat kasar menjadi produk yang mendukung peningkatan performan dan produksi (Samadi et al., 2010). Kulit singkong merupakan salah satu bagian limbah dari singkong yang cukup terkenal dikalangan peternak sebagai pakan ternak ruminansia. Hasil pengamatan kandungan nutrien kulit singkong yang sudah dikeringkan ini kadar protein kasarnya cukup rendah sekitar $6,67 \%$. Baik secara langsung diberikan maupun dilakukan berbagai perlakuan pengolahan teknologi pakan ternak. Menurut Oboh (2006) bahwa kulit singkong digunakan sebagai sumber karbohidrat terlarut karena kandungan BETN sebesar $64,6 \%$. Tingginya kandungan BETN dari kulit singkong akan berbanding lurus dengan kecernaan pakan yang tinggi pula sekitar 82,23\% (Hanifah et al., 2010). Oleh karena itu kulit singkong sangat berpotensi dimanfaatkan sebagai pakan sumber energi ternak ruminansia (sapi, kambing, kerbau dan domba. Kebutuhan ternak ruminansia akan pakan dapat dihitung berdasarkan beberapa acuan yang telah dikenala luas. NRC (1984) mengatakan bahwa kebutuhan pakan ternak ruminansia (1 ST) terhadap bahan kering 6,25 $\mathrm{kg} / \mathrm{ha}$. Perhitungan kapasitas dukung ternak sebagai berikut: 
Data hasil penelitian menunjukkan bahwa populasi sapi potong pada dusun Batur Ngisor dan Tutup Ngisor sebanyak 121 ekor disajikan pada tabel 2. Jika jumlah tersebut ternak dewasa maka populasi sapi potong sebanyak 121 ST (satuan ternak). Jadi, dengan perhitungan daya dukung kulit singkong hasil olahan pothil sebagai pakan sapi potong Kecamatan Dukun khususnya dusun Batur Ngisor dan Tutup Ngisor menambah populasi sapi potongnya sekitar 55 kali lipat dari populasi awal.

\begin{tabular}{|c|c|c|c|c|c|}
\hline \multirow[b]{2}{*}{$\begin{array}{l}\mathbf{N} \\
\mathbf{0}\end{array}$} & \multirow[b]{2}{*}{$\begin{array}{c}\text { Dusu } \\
\text { n }\end{array}$} & \multirow[b]{2}{*}{ Desa } & \multicolumn{3}{|c|}{ Ternak Ruminansia } \\
\hline & & & $\begin{array}{c}\text { Sapi } \\
\text { Poton } \\
\text { g } \\
\text { (ekor } \\
\text { ) }\end{array}$ & $\begin{array}{c}\text { Kerba } \\
\mathbf{u} \\
\text { (ekor) }\end{array}$ & $\begin{array}{c}\text { Kambi } \\
\text { ng } \\
\text { (ekor) }\end{array}$ \\
\hline 1 & $\begin{array}{l}\text { Batur } \\
\text { Ngis } \\
\text { or }\end{array}$ & $\begin{array}{l}\text { Ngargomul } \\
\text { yo }\end{array}$ & 81 & 4 & 6 \\
\hline 2 & $\begin{array}{l}\text { Tutu } \\
\text { p } \\
\text { Ngis } \\
\text { or }\end{array}$ & $\begin{array}{l}\text { Desa } \\
\text { Sumber }\end{array}$ & 40 & 2 & 30 \\
\hline \multicolumn{3}{|c|}{ Total } & 121 & 6 & 36 \\
\hline
\end{tabular}

Kulit singkong dapat digunakan sebagai hijauan dan pakan sumber energi bagi ransum ternak ruminansia. Beberapa perlakuan meliputi pengeringan, ensilase dan fermentasi diterapkan guna mengurangi kandungan $\mathrm{HCN}$ yang menjadi racun saat diberikan untuk pakan ternak. (Pipat Lounglawan et al., 2011; Smith, 1988).

Hasil pengukuran kandungan nutrien kulit singkong yang sudah dikeringkan yaitu Bahan Kering 90,56\%,; Serat Kasar 10,58\%; Lemak Kasar 1,98\%; Protein Kasar 6,76\%; Kadar Air 9,44\%; Kadar abu 3,37\%; Kalsium 1,31\% dan Phospor $0,38 \%$. Berdasarkan hasil penelitian menunjukkan nilai kandungan nutrien kulit singkong yang telah dikeringkan dari hasil olahan pothil berpotensi dimanfaatkan sebagai pakan sapi potong. Bahwa kebutuhan nutrien akan lemak kasar, Calsium dan phosphor sudah dapat terpenuhi dari kulit singkong tersebut. Sedangkan untuk kandungan protein kasar kulit singkong sekitar $6,76 \%$ (pothil) belum mampu mencukupi kebutuhan nutrien jika dimanfaatkan sebagai pakan ternak secara tunggul. Kebutuahan protein sapi potong akan tercukupi melalui kombinasi penggunaan bahan pakan yaitu kulit singkong dan bahan pakan lain yang kandungan protein lebih tinggi sebagai pelengkap kekurangan kebutuhan protein. Menurut Smith (1988) kulit singkong tidak dianjurkan untuk diberikan secara tunggal tanpa bahan pakan pendamping lainnya. Hal tersebut dikarenakana kandungan protein dan mineral tidak dapat mendukung fungsi dan produktivitas rumen secara optimal. Pemanfaatan kulit singkong secara optimal melalui suplementasi pakan bersama protein yang mudah difermentasi dan protein by-pass, termasuk sulfur, fosfor, dan vitamin B. Potensi kulit singkong cukup besar, ketika dimanfaatkan sebagai pakan secara seimbang, oleh karena itu kulit singkong merupakan pakan yang berharga bagi ruminansia (Smith, 1988).

\section{KESIMPULAN}

Hasil penelitian menunjukkan bahwa produksi bahan kering kulit singkong dari olahan pothil di Kecamatan Dukun sebesar 506.795,02 ton/tahun. Jika dihitung berdasarkan daya dukung kulit singkong dari olahan pothil tersebut, maka Kecamatan Dukun mampu menampung sekitar 6768 ST (satuan ternak) atau 6768 ekor sapi potong dewasa setiap tahunnya. Oleh karena itu, kulit singkong dari olahan pothil di Kecamatan Dukun mampu mencukupi kebutuhan pakan bagi sapi potong.

\section{REFERENSI}

Badan Pusat Statistik Kabupaten Magelang. 2018. Kabupaten Magelang dalam Angka.

Hanifah, V.W., D. Yulistiani dan S.A.A Asmarasari. 2010. Optimalisasi pemanfaatan limbah kulit singkong menjadi pakan ternak dalam rangka memberdayakan pelaku usaha enye-enye. Seminar Nasional Teknologi Peternakan dan Veteriner.

NRC. 1984. Nutrient Requirement of Beef Cattle, National Academy of Science, Washington, DC.

Oboh, G. 2006. Nutrient enrichment of cassava peels using a mixed culture of Saccharomyces cerevisae and Lactpbacillus spp. Solid media fermentation Techniques. Electronic $\mathrm{J}$. Biotechnol. 9(1), Issue of January 15, 2006 DOI: 10.2225?vol9-issues1-fulltext-1.

Samadi, Y. Usman dan M. Delima. 2010. Kajian potensi limbah pertanian sebagai pakan ternak ruminansia di Kabupaten Aceh Besar. Agripet. 10(2):45-53.

Smith, O.B., 1988. A review of ruminant responses to cassava-based diets. In: Hahns, S.K., Reynolds, L., Egbunike, G. N (Eds). Cassava as livestock in Afrika 